Università degli Studi di Salerno

Centro di Economia del Lavoro e di Politica Economica

Ugo Colombino*, Annamaria Nese**

* UNIVERSITY OF TURIN, DEPARTMENT OF ECONOMICS

COGNETTI DE MARTIIS

** UNIVERSITY OF SALERNO, DEPARTMENT OF ECONOMICS

AND STATISTICS AND CELPE

Preference Heterogeneity in Relation to Museum Services

Corresponding author:

anese@unisa.it

Discussion Paper 105 
Scientific Commitee:

Adalgiso Amendola, Floro Ernesto Caroleo, Cesare Imbriani, Pasquale Persico, Salvatore Vinci

C.E.L.P.E.

Centro di Ricerca Interdipartimentatle di Economia del Lavoro e di Politica Economica Università degli Studi di Salerno

Via Ponte Don Mellillo, 84084 Fisciano, I- Italy

http://www.celpe.unisa.it

E-mail: celpe@unisa.it 
Indice

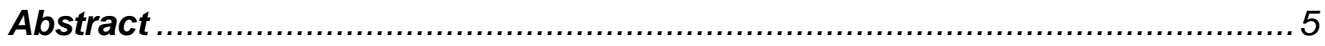

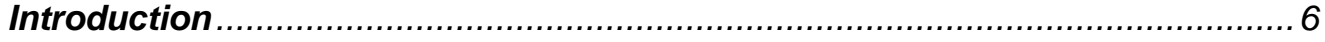

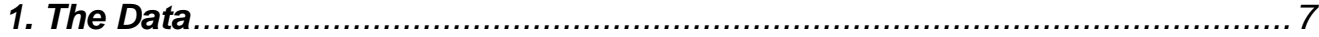

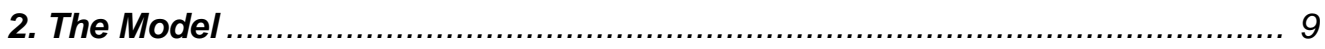

3. Logit Model with Fixed Parameters .............................................. 12

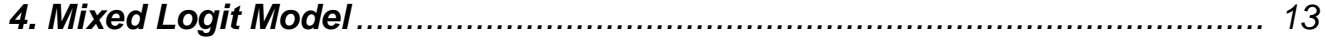

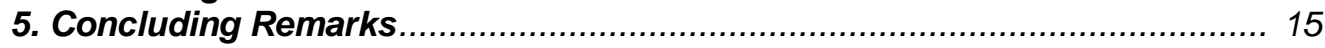

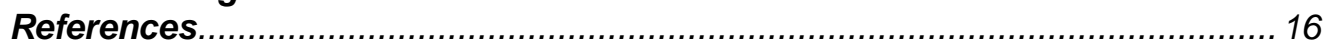

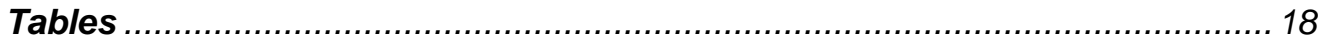




\title{
Preference Heterogeneity in Relation to Museum Services
}

\author{
Ugo Colombino*, Annamaria Nese* \\ * UNIVERSITY OF TURIN, DEPARTMENT OF ECONOMICS \\ COGNETTI DE MARTIIS \\ ** UNIVERSITY OF SALERNO, DEPARTMENT OF ECONOMICS \\ AND STATISTICS AND CELPE
}

\begin{abstract}
The prevailing trends in the management of European museums underline the importance of additional museum services in fostering and encouraging the optimisation of cultural assets, while facilitating the collection of the necessary resources for conservation. The paper considers the case of the archaeological site of Paestum (Salerno) and presents an analysis of individual preferences in relation to specific policies of cultural heritage management, each characterised by the supply of different museum services. Since the diversity of these services can prompt different individual preferences, the analysis allows for heterogeneity of parameters among individuals.
\end{abstract}

JEL classification: D12, Z1

Keywords: cultural goods, heterogeneous preferences, stated preference data, conjoint analysis, mixed logit

Acknowledgements: We thank two anonymous referees for their useful comments. Usual disclaimers apply. 


\section{Introduction}

The debate between cultural heritage managers and tourism proponents has often implied a conflict relationship (McKercher et al., 2005): some were more likely to prioritise the conservation of cultural assets, some others were more interested in increasing the tourist flow for its favourable effects on income and employment. This conflict relationship has been overcome: economists, policy makers and specialists in the field of cultural goods recognise that cultural tourism exerts on monuments and sites a positive effect since it contributes to their maintenance and protection (socio-cultural and economic benefits deriving from cultural tourism justify the efforts for cultural heritage preservation); at the same time, public fruition of cultural heritage must be cautiously monitored for preservation aims ( ICOMOS, 1999).

More specifically, the current debate underlines the importance of adequate management policies in order to promote a sustainable fruition of cultural heritage (Frey and Pommerehnne, 1989; Frey, 1994; Trimarchi, 1999; Di Maio, 1999; ICOMOS, 1999; Amendola and Nese, 2005). To this aim, a main challenge is to properly define museum services that "put the Museum in touch with its public". Hence the importance of taking also visitors' preferences into account and, most of all, understanding how these preferences vary within the population. A successful design of services must match visitor's preferences and by extracting (part of) visitors' surplus can provide financial support also in view of conservation. Thus, accounting for heterogeneous preferences emerges as a crucial issue in the analysis of visitors' choices.

This paper aims at analysing individual preferences for museum services associated with different strategies for managing cultural heritage (such as opening times, possibility to arrange guided tours, interactive labs, etc.). The attention focuses on three alternative policies of cultural heritage management: a first one mostly concerned with the improvement of museum services related to public access and understanding of the cultural site; a second policy package mainly aimed at enhancing educational purposes; a third one centred on entertainment and leisure. These three aims are not thoroughly compatible, though museum management policies should attempt - to some extent - to integrate them.

The analysis is carried out using stated preference data collected at the archaeological site of Paestum ${ }^{1}$, which has been listed among the UNESCO

\footnotetext{
${ }^{1}$ The data used in the analysis have been collected with a survey financed by the Campania Region under Law 46/97. The survey was carried out at the Department of Economic and Statistics of the University of Salerno by: Adalgiso Amendola, Ugo Colombino, Annamaria Nese, Patrizia Riganti, Pier Luigi Russo.
} 
World Heritage Sites since 1998. In particular, the available data are based on declared preferences about different museum services and, for each individual, a certain number of choices made are available.

The Contingent Valuation method has become increasingly popular in cultural economics covering a considerable range of topics and debating numerous issues (broad reviews are in Carson et al., 2001; Navrud and Ready, 2002; Noonan, 2003). While many CVM studies address the problem of estimating the economic value of cultural resources, or the WTP for their preservation, other studies measure WTP for admission or service improvements (Mazzanti, 2002; Colombino and Nese, 2005; Riganti et al., 2006); CVM studies about museum services are particularly interesting in that they provide useful information to museum managers.

The review by Noonan (2003) points out that research design in CVM studies about cultural heritage is complicated by the existence of positive WTP from some groups and negative or zero WTP from others. The specific issue is that "cultural goods like major public art displays often evoke passionate and diametrically opposed responses, perhaps because these goods bear closely on individual identities" (Noonan 2003, p. 162). Hence, a more complete picture of individual behaviour is necessary in order to understand not only the average willingness to pay, but also the extent to which individuals with different tastes are affected by different policies.

In order to model preference heterogeneity, an increasing number of studies, mostly analysing recreational demand or transportation research, have used the random parameter model, or mixed logit (Train 1998). This model allows testing for the existence of a statistically significant distribution of the coefficients across individuals. More specifically, a mixed logit model allows for random variation parameters due to unobserved characteristics, whereas the standard logit model allows taking into account only taste variations due to observed characteristics.

Currently, the mixed logit is considered one of the most promising discrete choice methods available to analyse questionnaire data (Correia et al., 2007; Hensher and Green, 2003). Applications include Train (1998), Brownstone and Train (1999), Mc Connel and Tseng (2000), Breffle and Morey (2000); CVM applications concerning environmental topics are in Layton (2000), Layton and Brown (1999), Nahuelhual et al. (2004).

As far as the CVM studies on cultural heritage are concerned, Morey and Rossman (2003) use the mixed logit model to investigate variations in WTP for preserving 100 marble monuments in Washington. The authors underline that, for applications to cultural resources, the researcher must test for the possibility that specific programs may be "good" for some people, "bad" for others: the problem, again, is that "cultural resources, such as this set of monuments, represent culture, history institutions and artistic achievements, and opinions as to their value (positive or negative) are likely to differ" (Morey and Rossman, p. 215).

The current work contributes to this literature by exploring the implications of the use of the Mixed Logit model in the analysis of preference heterogeneity for museum services. The specific issue is that the diversity of museum services, characterising different cultural heritage management options, could 
prompt heterogeneity in individual preferences: even if the extreme positions of conservationism tout court on the one hand, and of massive and uncontrolled tourism on the other, may be considered overcome, heterogeneous preferences do persist in the "middle". For example, a cafèbar, or concerts inside the archaeological site, may be considered positively by some people, negatively by others. This information is obviously important for the policy makers, who must balance the welfare of different people rather than managing for the average person (Nahuelhal et al., 2004).

The paper is structured as follows: Section 1 introduces the data, Section 2 describes the model. Sections 3 and 4 deal with the results of the estimates obtained using, respectively, the logit model with fixed parameters and the mixed logit models; the models presented are compared on the basis of their explicative power. Section 5 draws the paper's conclusions.

\section{The Data}

The data used for the analysis have been collected during a survey carried out in August 2002 at the archaeological site of Paestum ${ }^{2}$ (Salerno) in order to analyse individual preferences in relation to the site's different management options. The sample was composed by 732 individuals, mainly tourists, during their visit at the archaeological site. Each sampled visitor was asked to choose among three different scenarios, defined by a list of characteristics (to be explained hereafter) and by the price of the entrance ticket. On the basis of a description of the most widespread services in European museums (Russo, 2005), and having considered the specificity of the site of Paestum, the survey has taken the following site characteristics into account:

1) Opening hours until 5 p.m., or extended opening time until 10 p.m.

2) Audio-guides for the visits to the excavations and the Museum.

3) Hourly guided tours.

4) Panoramic café-bar overlooking the excavations.

5) Thematic exhibitions

6) Cultural events (classical/light music concerts and theatre performances).

7) Teaching laboratory for kids.

8) Projection of audiovisual material during the visit to the Museum and the excavations for a virtual reconstruction of the site.

9) Computerised documentation centre providing information on similar sites existing in the area.

\footnotetext{
${ }^{2}$ Paestum was a Greek colony, founded around 600 B.C. under the name Poseidonia. It is famous in the world mainly for its temples, generally considered as being among the best preserved Doric temples in existence today: the Poseidon temple, the Ceres temple, the Basilica of Hera. In 273 B.C. the Romans took possession of the city and renamed it to Paestum; the most important ruins belonging to the Roman period are the Forum and the Amphitheatre. The Museum, near the archaeological site, collects a lot of finds coming from the city and the territory of Paestum; it keeps, for example, the tomb of the diver, an important example of classical painting.
} 


\section{0) Ticket price.}

Characteristics (1) - (9) are measured as 0-1 dummies. The ticket price varies between ITL 12,000 (= $€ 6.20)$ and ITL 25,000 (=€ 12.91). The different ticket prices were derived using information about individual willingness to pay collected in the focus group and in a pre - test.

Museum services 1) to 3 ) essentially respond to the need to facilitate both the visit and the understanding of the cultural site; services 7), 8) and 9) aim at enhancing the site's educational purposes; while initiatives 4) to 6) tend to promote the visit to the archaeological site as a particularly attractive leisure activity.

Preferences for some specific categories of services rather than others are crucial in order to understand the type of strategy to be pursued and define different policies for the museum organization and management.

Each interviewee is asked to choose a favourite scenario (that is to say, the favourite combination of museum services) from each of the four cards presented by the interviewer. Each card contains the description of three alternative scenarios: scenario "A", the same for all cards, offers the basic essential services to visit the site (i.e. all the characteristics 1-9 are set equal to 0 ); scenarios $\mathrm{B}$ and $\mathrm{C}$ consist of a higher fare ticket and a different combinations of the extra services listed above. On a rotation basis, an overall number of 24 cards were submitted (the submission order varied regularly in order to avoid ordering bias). The different combinations of services in scenarios other than A were derived from an orthogonal factorial combination of them, checking for their realism and removing the dominated alternatives (e.g. packages characterized by more expensive services and a cheaper ticket price $)^{3}$. An example of card is in table 1.1.

Table 1.2 shows the distribution of choices made for different alternatives; scenario A, for instance, was only chosen 287 times, accounting for $9.95 \%$ of the compiled cards; among the alternatives listed on the first card, scenario A was chosen $3.33 \%$ of the times. This suggests that, on the whole, interviewees tend to prefer a wider range of services offered despite a higher price to be paid.

\section{The Model}

We first consider a standard multinomial logit model (henceforth $\mathrm{ML}$ ). The utility of person $n$, if he chooses the scenario $j$ among $J$ alternatives is specified as:

$$
\mathrm{U}_{n j} ? ?^{\prime} x_{n j} ?{ }^{n j}
$$

\footnotetext{
${ }^{3}$ A deeper description of the stages of questionnaire development and implementation is in Riganti (2005) and in Riganti et al. (2006).
} 
where $\mathrm{x}_{n j}$ are observed variables that relate to the alternative and the decision maker, ? is a vector of (fixed) parameters to be estimated and $?_{n j}$ is a random variable i.i.d. according to the Type I extreme value distribution. The decision maker chooses alternative $\mathrm{i}$ if and only if $U_{n i}$ ? $U_{n j}$, with $\mathrm{j}$ ? i. The probability that individual $\mathrm{n}$ chooses alternative i turns out to be :

$$
\mathrm{P}_{n i} ? \frac{e^{b^{\prime} x_{n i}}}{?_{j} e^{b^{\prime} x_{n j}}}
$$

In a second stage of the analysis, we drop the assumption of fixed taste parameters and adopt the Mixed Logit (henceforth MXL) model. The utility of individual $n$ choosing alternative $\mathrm{j}$ is now specified as:

$$
\mathrm{U}_{n j} ? ?{ }_{n}^{\prime} x_{n j} ? ?{ }_{n j}
$$

where ${ }_{n}$ is a (individual-specific) vector of parameters that represents the marginal utilities of the characteristics $\mathrm{x}_{n j}$ for individual $\mathrm{n}, \mathrm{x}_{n j}$ is a vector of characteristics and $?_{n j}$ is a random term distributed as in the ML model.

If $f$ ?? ? is the probability density function of ? the choice probability is obtained by computing the expectation of (2) with respect to the density function of ? , that is:

$$
\mathrm{P}_{n i} ? \stackrel{?}{?} \frac{e^{? x_{n i}}}{?} ?_{?}^{?_{j} e^{? ' x_{n j}}} \stackrel{?}{?} ?
$$

Therefore, in applying a MXL model, the researcher does not estimate the coefficients ?, but the parameters ? of the density function of ? (e.g. the mean and the variance-covariance matrix of?). The distributions generally found in the literature are the normal, lognormal, uniform and triangular distributions (Train, 2003). The lognormal distribution is useful when the coefficient is known to have the same sign for every decision maker; this is the reason why lognormal distribution is generally used to estimate the price 
coefficient. However, as remarked by Ruud (1996), the use of a lognormal distribution for the price coefficient can lead to estimate a very low value (and, consequently, a high willingness to pay). At the same time, Ruud suggests maintaining a fixed price coefficient in order to solve the problem of the parameters' instability, which is frequent if all coefficients are assumed to be variable. The uniform and triangular distribution have the advantage of being limited between the values " $b-s$ " and " $b+s$ " (where the mean $b$ and the spread $s$ are the parameters to be estimated). By doing so, there is no risk to estimate exceedingly high values for the coefficients, a problem that could occur using the normal distribution (Train, 2003).

The integral appearing in expression (4) cannot be evaluated in closed form, but simulation methods are necessary. In practice, $M$ values of $?\left(?{ }^{1}, ?^{2}, \ldots, ?^{M}\right)$ are sampled from the chosen distribution $f(?)$ and, on the basis of these values, the simulated probability is calculated:

$$
\mathrm{P}^{\wedge}{ }_{n i} ? \frac{1}{M} ?_{m ? 1}^{M} \frac{e^{?^{m^{\prime}} x_{n j}}}{?_{j} e^{?^{m^{\prime}} x_{n j}}}
$$

The simulated probabilities are inserted into the likelihood function to obtain a simulated likelihood. The distribution parameters $f(?)$ are therefore obtained by maximising the simulated likelihood.

The model is easily generalised to allow for repeated choices by the same decision maker (stated preference data). Utility for alternative $\mathrm{j}$ in choice situation $\mathrm{t}$ by person $\mathrm{n}$ is:

$$
\mathrm{U}_{n j t} ? ?_{n} x_{n j t} ? ?{ }_{n j t}
$$

Choice probabilities are obtained multiplying the logit formulas (2), one for each choice situation, and then calculating again the expected value in relation to the density function of ? :

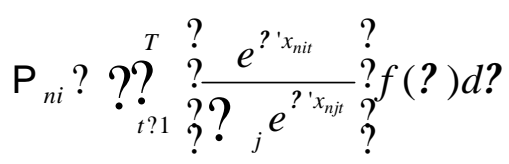

The probability is computed by simulation in the same way as in the singlechoice setting. In this specification of the model, parameters ? are assumed 
to be constant over different "choice situations". This assumption is particularly appropriate if stated preference data are used (Train, 2003).

Recent developments in the use of simulation techniques have encouraged a more widespread use of the mixed logit model in applied microeconomics, though problems related to the identification of the model are often overlooked. Difficulties in the identification of the model can often be evinced by very high standard errors, by the instability of the parameters due to an increased number of draws used in simulation, or by the choice of different starting values (Walker, 2002). As underlined by Chiou and Walker (2005) for instance, a low number of draws may lead to estimate a model that appears to be identified but that actually is not; besides, the correct number of draws to be used depends on the data, the model and the type of draws (pure random versus Halton draws ${ }^{4}$ ). The researcher should therefore verify the stability of parameters according to the increase in the number of draws and to the variation in the starting values used in the estimation procedure.

\section{Logit Model with Fixed Parameters}

The data collected with the conjoint analysis method - as briefly described in Section 1-were initially used to estimate the parameters of the ML model. The observations with missing values for at least one of the variables used are eliminated to obtain a sample of 704 individuals. If all the choices made by each individual are taken into account, the number of observations amounts to 2816 (since each sampled individual chooses the favourite scenario from 4 different cards).

Table 3.1 contains the parameters' estimates, the standard errors and the WTP for each additional service inside the archaeological park.

All the estimated coefficients are significantly different from zero; the most interesting results concern the WTP for each museum service. Services that the visitors are more willing to pay for are guided tours and extended opening hours, followed by the availability of teaching laboratories for kids. The lowest WTP is observed for "thematic exhibitions" while a negative WTP is obtained for a café-bar inside the archaeological area. Therefore, the results indicate a preference for the possibilities to optimise the use and the appreciation of the cultural site, followed by an interest in the educational purposes of the visit. Thus, in line with Verbeke and van Rekom (1996), the main reason for visiting a museum still remains the wish to "learn something".

As already outlined above, each sampled individual was asked to choose four times (each time, from a different card) among the scenario " $A$ " and two alternative combinations of museum services. The estimates reported in table 3.1 have been obtained using 2816 observations (4 repeated choices x 704 individuals). Moreover, in an attempt to identify a possible taste variation for

\footnotetext{
${ }^{4}$ Bhat (2001) demonstrated, for example, that 100 Halton draws provide more accurate results than 1000 pure random draws.
} 
the same individual in the four "choice situations", the ML model has been used also to analyse the choices made by 704 individuals for each of the four cards. In particular, data in table 3.2, column 1, refer to the choices made by the sampled individuals in relation to the first card submitted by the interviewer, data listed in column 2 refer to the choices made in relation the second card, etc.

A Wald test (Liao, 2004) was used to test the stability of parameters in different choice situations. In particular, the aim was to verify the equality between the coefficients listed in table 3.2 and 3.1 ; therefore, the null hypothesis of the test is the following:

$$
\mathrm{H}_{0}: ?_{k} ? ? *
$$

where $?_{k}$ indicates the coefficients estimated using 704 observations (in table $3.2, k=1,2,3,4)$, and ? * indicates the parameters estimated using the 2816 observations (table 3.1 ).

The statistics of the test is:

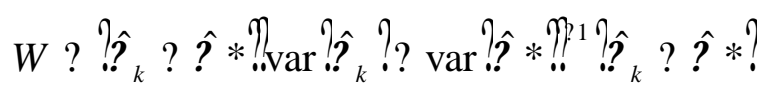

where var $(\cdot)$ is the variance-covariance matrix of the parameters. The statistics is asymptotically distributed as chi-squared with degrees of freedom equal to the number of parameters. The values of the statistics, presented in the last row of table $3.2^{6}$, do not, in any case, indicate significant differences between the parameters presented in table 3.1 and those in table 3.2. The assumption in (6) seems therefore appropriate: individual tastes do not vary between different "choice situations".

\section{4. $\quad$ Mixed Logit Model}

This section reports the estimates obtained using the Mixed Logit model. The advantage of this technique is that it allows parameters to vary across

\footnotetext{
${ }^{5}$ We consider as different choice situations the choices made in relation to different cards.

6 The Wald test can also be used to compare single coefficients. The statistics of the test becomes:

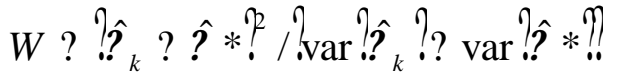

The statistic is distributed as chi-squared with 1 degree of freedom. In this case it is not necessary to know the variance-covariance matrix. However, the Wald statistic could be inconsistent in this case (though such anomaly rarely occurs (Mantel, 1987)).
} 
individuals so that researchers can predict how different policies affect individuals with different tastes and, consequently, how the benefits are shared by the population (i.e. for distributional purposes) ${ }^{7}$.

A number of 2816 observations was used to estimate the parameters of the mixed logit model ${ }^{8}$. We experimented different types of distribution, namely the normal, triangular and uniform distribution. Therefore, a priori assumptions on the coefficients' sign were avoided: some individuals might be in favour of the organization of events such as fashion shows or concerts inside the archaeological area; some others could be against, fearing possible damages to the site. Some may even be in favour of a particularly expensive ticket so as to reduce the possible negative consequences of mass tourism ${ }^{9}$.

The results are reported in Tables 4.1 and 4.2. For each attribute there are two rows. The first row contains the estimate of the mean of the corresponding ? and the standard error of the estimate, respectively under the assumptions of a normal (I), uniform (II) or triangular (III) parameters' distribution. The second row contains the estimate of the variance (or of the spread in the case of the uniform and of the triangular distribution) and the standard error of the estimate. For example, assuming that the parameters have a uniform distribution, Table 4.1 tell us that the marginal utility of Audio guides on average is equal to 1.394 and that its spread among the visitors is equal to 2.243. It appears that all the estimates of the mean of ? are very similar whatever the distributional assumptions. It is worthwhile noticing that all the variances are significantly different from zero at standard levels of significance, which supports the choice of a model like MXL that allows for unobserved preference heterogeneity.

Table 4.2 reports the results of a second estimation exercise. In order to test whether the results are affected by the estimation procedure, we produce a second set of estimates, obtained by changing the starting values used by the maximization algorithm and the number of draws used to build the simulated log-likelihood (i.e. the value of $\mathrm{M}$ in expression (5). The exercise is limited to the uniform distribution cases. By comparing the estimates contained in table 4.1, second column, and table 4.2, first column, obtained using a uniform distribution of the parameters, the same number of draws $(4,000)$, but different starting values, some slight differences emerge; these differences are, however, never significant ${ }^{10}$. If the number if draws is increased from 4,000 to 40,000 , and the same starting values are maintained, some slight differences still occur in the estimated parameters, again not significant ${ }^{11}$. The most interesting comparison concerns the data listed in the second and third

\footnotetext{
${ }^{7}$ Glasgow (2001), for example, demonstrated that models which ignore heterogeneity gave an incomplete understanding of the role of union membership in determining vote choice in the 1992 US presidential election.

${ }^{8}$ The estimate of the Mixed Logit Model was based on a non-commercial code implemented in GAUSS, downloadable from Kenneth Train's web page: http://elsa.berkeley.edu/train.

${ }^{9}$ Apart from explicit acts of vandalism, human presence on archaeological sites generally implies erosion, which is caused by physical contact, vibrations produced by steps or sounds, etc.

${ }^{10} \mathrm{~A}$ Wald test carried out on single parameters never indicated significant differences.

${ }^{11}$ See note 6.
} 
column of table 4.2, obtained using 40,000 draws and different starting values. In this case, the estimated parameters are almost identical.

Let us compare the estimates contained in table 4.2 with those in table 3.1. On the basis of the Bayesian Information Criterion ${ }^{12}$ (Schwarz, 1978), the increase in number of parameters is more than compensated by a better adjustment to the data of the MXL model, thus confirming the hypothesis of a high heterogeneity of individual preferences.

As far as the interpretation of the estimated parameters is concerned, it is first of all worth underlining that all coefficients were estimated with a positive sign, except for the coefficients related to the café-bar in the park and to the entrance ticket price.

Table 4.3 reports the percentage of visitors who give a positive value to the attributes and the WTP for the attributes. The computations are based on the estimates (type III) of Table 4.2. The WTP for each attribute is obtained by dividing the mean of its coefficient ${ }_{k}$ by the mean of the coefficient (in absolute value) of the entrance ticket price ${ }^{13}$. In line with the estimates of the ML model, it can be noted that there is still a higher WTP for services that facilitate the accessibility and the understanding of the cultural site; at the same time, a negative WTP is observed for a café-bar inside the archaeological area, while the lowest WTP is reported for the other two attributes more centred on entertainment and leisure (exhibitions and events). However, MXL estimates indicate that these results are not fully shared by the population. In particular, the analysis of data in table 4.3 (first column) shows how the opinion on a café-bar inside the site is not thoroughly shared, with a good percentage (46\%) expressing a positive reaction. $28 \%$ of the population, on the contrary, prefers packages of museum services at a higher price. If other services are taken into account, the percentage of individuals who - against the prevailing trend - expresses a negative opinion is about $30 \%$, except for the higher frequency of guided tours (about $21 \%$ ) and the organisation of events (about $36 \%$ is against).

\section{Concluding Remarks}

The analysis of individual preferences for different museum services, both using the ML and the MXL model, leads to the conclusion that the most preferred services are those geared towards optimising the site's accessibility and understanding (e.g. extended opening hours, frequent guided tours within the archaeological site) and enhancing the visit's educational purposes (in

\footnotetext{
${ }^{12}$ The Bayes Information Criterion $(B I C)$ is computed as $-2^{*} \ln ($ likelihood $)+p^{*} \log (N)$, where $p$ indicates the number of parameters, $\mathrm{N}$ the number of observations. The model with the highest explicative power is identified on the basis of a lower BIC.

${ }_{13}$ This is obviously an approximation: a more sophisticated procedure would consist in determining the distribution of the WTP on the basis of the distribution of the numerator and of the denominator.
} 
particular, the presence of teaching interactive labs), while a lower interest is shown in relation to the transformation of the site in a place of leisure and entertainment, with the organisation of events or the opening of a café-bar. The analysis based on the MXL model revealed, however, that these preferences vary significantly within the population. The opinion on a café-bar inside the site, for example, is not thoroughly shared, with a good percentage (46\%) expressing a positive reaction. On the other hand, $36 \%$ of the population is against the organisation of events.

Turning to the methodological issues addressed by the paper, a first remark is that the MXL model - using Bayes Information Criterion - displays a much higher explicative power then the ML model, and reveals a very significant heterogeneity of taste parameters in the population. A second key remark is that the (distributions of the) coefficients of the MXL model remain stable as the number of draws and starting values increase, in contrast to what is observed by Ruud (1996). In conclusion, it was possible, using stated preference data, to verify the stability of (the distribution of) "individual tastes" in different choice situations and under different simulated-estimation procedures. 


\section{References}

Amendola, A. and Nese, A. (2005), Modelli per la Gestione e la Valorizzazione del Patrimonio Culturale, Edizioni Scientifiche Italiane, Napoli, pp. 5-15.

Ben - Akiva, M. and Lerman, S.R. (1985), Discrete Choice Analysis, MIT Press, Cambridge Mass.

Bhat, C.R. (1996), "Incorporating observed and unobserved heterogeneity in urban work travel choice modelling", Department of Civil Engineering, working paper, University of Massachussets at Amherst.

Bhat, C.R. (2001), "Quasi random maximum simulated likelihood estimation of the mixed multinomial logit model", Transportation Research, 37, 681-698.

Breffle, W. and Morey E. (2000), "Investigating preference heterogeneity in a repeated discrete - choice recreation demand model of Atlantic salmon fishing", Marine Resource Economics, 15, 1-20.

Chiou, L. and Walker, J. (2005), "Identification and estimation of mixed logit models under simulation methods", mimeo.

Carson, R.T., Flores, N.E. and Meade, N.F. (2001), "Contingent valuation: controversies and evidence", Environmental and Resource Economics, 19 (2), 173210.

Colombino, U. and Nese, A. (2005), "Disponibilità a pagare per i servizi museali: i risultati dell'analisi econometria", in Modelli per la Gestione e la Valorizzazione del Patrimonio Culturale (Eds.) A. Amendola and A. Nese, Edizioni Scientifiche Italiane, Napoli, pp. 167-177.

Correia A., Barros C. P. and Silvestre A.L. (2007), "Golf tourism repeat choice behaviour in the Algarve: a mixed logi approach", Tourism Economics, 13 (1), 111127.

Cuccia, T. and Cellini R. (2007), "Is cultural heritage really important for tourists? A contingent rating study", Applied Economics, 39 (2), 261-271.

Di Maio A. (1993), Economia dei beni e delle attività culturali, Liguori, Napoli.

Frey B.S. and W.W. Pommerehne (1989), Museums and markets; explorations in the economics of arts, Blackwell, Oxford.

Frey B.S. (1994), "Cultural economics and museum behaviour", Scottish Journal of Political Economy, 41.

Hensher, D.A. and Greene, W. (2003), "The mixed logit model: the state of practice", Transportation, 30(2), 133-176.

ICOMOS, (1999) "International cultural tourism charter. Managing tourism at places of heritage significance". Mexico: ICOMOS. http://.icomos.org.

Layton, D. (2000), "Random coefficient models for stated preference surveys", Journal of Environmental Economics and Management, 40, 21-36.

Layton, D. and Brown G. (2000), "Heterogeneous preferences regarding global climate change", Review of Economics and Statistics, 82 (4), 616-624.

Liao, T. F. (2004), "Comparing social groups: Wald statistics for testing equality among multiple logit models", SAGE Publications, www.sagepublications.com.

Mantel, N. (1987), "Understanding Wald's test for exponential families", The American Statistician, 41, 147-148.

Mazzanti M. (2001), "Discrete choice models and valuation experiments: an application to cultural heritage", working paper SIEP n. 75.

McConnel, K. and Tseng W. (2000), "Some preliminary evidence on sampling of alternatives with the random parameter logit", Marine Resources Economics, 14, 317332.

Mc Fadden, D. and Train, K. (2000), "Mixed MNL models for discrete response", Journal of Applied Econometrics, 15, 447-470. 
McKercher B., Ho P.S.Y. and du Cros H., (2005), "Relationship between tourism and cultural heritage management: evidence from Hong Kong", Tourism Management, 26 (4), 539-548.

Morey E. and Rossman K.G., (2003), "Using stated-preference questions to investigate variations in willingness to pay for preserving marble monuments: classic heterogeneity, random parameters, and mixture models", Journal of Cultural Economics, 27 (3-4), 215-229.

Nahuelhual L., Loureiro M.L. and Loomis J., (2004), "Using random parameters to account for heterogeneous preferences in contingent valuation of public open space", Journal of Agricultural and Resource Economics, 29, 537-552.

Navrud S. and Ready R.C. (eds) (2002), Valuing cultural heritage: applying environmental valuation techniques to historic buildings, monuments and artefacts, Edward Elgar, Northampton, MA.

Noonan D. S. (2003), "Contingent valuation and cultural resources: a meta-analytic review of the literature", Journal of Cultural Economics, 27, 159-176.

Revelt, D. and Train K. (1996), "Mixed logit with repeated choices: household choices of appliance efficiency level", Review of Economics and Statistics.

Riganti, P. (2005), "La definizione del questionario di valutazione contingente per l'area archeologica di Paestum", in Modelli per la Gestione e la Valorizzazione del Patrimonio Culturale (Eds.) A. Amendola and A. Nese, Edizioni Scientifiche Italiane, Napoli, pp. 157-167.

Riganti, P., Nese, A. and Colombino, U. (2006), "A methodology for eliciting public preferences for managing cultural heritage sites", in Tourism and Regional Development (Eds) M. Giaoutzi and P. Nijkamp, Ashgate, Aldershot, UK, pp. 201219.

Russo, P. L. (2005), "Il settore museale: rassegna dei servizi aggiuntivi nell'ottica della valorizzazione complessiva dei beni culturali", in Modelli per la Gestione e la Valorizzazione del Patrimonio Culturale (Eds.) A. Amendola and A. Nese, Edizioni Scientifiche Italiane, Napoli, pp. 99-122.

Ruud, P. (1996), "Approximation and simulation of the multinomial probit model: an analysis of covariance matrix estimation", working paper, Department of Economics, University of California, Berkeley.

Scarpa R, Sirchia G. and Bravi M. (1998), "Kernel vs. Logit modelling of single bounded CV responses: valuing access to architectural and visual arts heritage in Italy", in Bishop R. and Romano D. (eds), Environmental resource valuation: applications of contingent valuation method in Italy, Kluwer Publisher, Boston.

Schwarz, G. (1978), "Estimating the dimension of a model", Annals of Statistics, 6, 461-464.

Train, K. (1998), "Recreation demand models with taste differences over people", Land Economics, vol 74 (2).

Train, K. (1999), "Halton sequences for mixed logit", working paper, Department of Economics, University of California, Berkeley.

Train, K. (2003), "Mixed Logit", in Discrete Choice Methods with Simulation, Cambridge University Press, Cambridge, pp. 138-155.

Trimarchi (1999), Economia e cultura, Franco Angeli, Milano.

Verbeke, J. and van Rekom, M. (1996), "Scanning museum visitors", Annals of Tourism Research, 23 (2), 364-375.

Walker, J. (2002), "The mixed logit (or logit kernel) model: dispelling misconceptions of identification", Transportation Research Record, 1805, 86-98. 


\section{Tables}

\begin{tabular}{llll}
\multicolumn{1}{c}{ Attributes } & \multicolumn{1}{c}{ Scenario A } & \multicolumn{1}{c}{ Scenario B } & \multicolumn{1}{c}{ Scenario C } \\
\hline Opening Time & 9 a. m-5 p.m. & 9 a.m. -10 p.m. & 9 a.m. -10 p.m. \\
Audio - guides & no & yes & yes \\
Café & no & yes & yes \\
Cultural events & no & no & yes \\
Exhibitions & no & yes & no \\
Laboratory & no & no & no \\
Audiovisuals & no & yes & yes \\
Document. Centre & no & yes & no \\
Price (2002 ITL) & 12,000 & 15,000 & 25,000
\end{tabular}

Table 1.1: Example of a card

\begin{tabular}{lrlll}
\multicolumn{1}{c}{ Cards } & $\begin{array}{c}\text { Scenario A } \\
\%\end{array}$ & $\begin{array}{c}\text { Scenario B } \\
\%\end{array}$ & $\begin{array}{c}\text { Scenario C } \\
\%\end{array}$ & Total \\
\hline Card1 & 3.33 & 30.00 & 66.67 & 100.00 \\
Card 2 & 3.33 & 49.17 & 47.50 & 100.00 \\
Card 3 & 3.33 & 41.67 & 54.17 & 100.00 \\
Card 4 & 4.17 & 58.33 & 37.50 & 100.00 \\
Card 5 & 19.08 & 51.91 & 28.24 & 100.00 \\
Card 6 & 19.85 & 46.56 & 32.82 & 100.00 \\
Card 7 & 20.61 & 35.88 & 42.75 & 100.00 \\
Card 8 & 19.08 & 24.43 & 55.73 & 100.00 \\
Card 9 & 8.26 & 19.83 & 71.90 & 100.00 \\
Card 10 & 5.79 & 60.33 & 33.88 & 100.00 \\
Card 11 & 8.26 & 22.31 & 69.42 & 100.00 \\
Card 12 & 12.40 & 33.88 & 53.72 & 100.00 \\
Card 13 & 5.83 & 48.33 & 45.83 & 100.00 \\
Card 14 & 5.83 & 44.17 & 50.00 & 100.00 \\
Card 15 & 5.83 & 30.00 & 64.17 & 100.00 \\
Card 16 & 7.50 & 24.17 & 68.33 & 100.00 \\
Card 17 & 10.00 & 20.00 & 64.17 & 100.00 \\
Card 18 & 8.33 & 72.50 & 17.50 & 100.00 \\
Card 19 & 10.00 & 80.00 & 6.67 & 100.00 \\
Card 20 & 10.00 & 45.00 & 42.50 & 100.00 \\
Card 21 & 8.33 & 55.83 & 32.50 & 100.00 \\
Card 22 & 10.83 & 70.00 & 15.00 & 100.00 \\
Card 23 & 10.83 & 41.67 & 41.67 & 100.00 \\
Card 24 & 10.83 & 68.33 & 15.00 & 100.00 \\
Total & 9.95 & 45.35 & 44.70 & 100.00
\end{tabular}

Table 1.2: Distribution of the alternatives chosen 


\begin{tabular}{lccc} 
Variables & Coefficients & Standard errors & $\begin{array}{c}\text { Willingness to pay } \\
\text { (in 2002 thousand ITL) }\end{array}$ \\
\hline Opening Time & 0.585 & 0.069 & 10.54 \\
Audio & 0.395 & 0.054 & 7.09 \\
Guides & 0.736 & 0.067 & 13.38 \\
Café & -0.217 & 0.069 & -3.81 \\
Exhibitions & 0.217 & 0.062 & 3.95 \\
Events & 0.463 & 0.072 & 8.36 \\
Laboratory & 0.652 & 0.072 & 11.81 \\
Audiovisuals & 0.356 & 0.059 & 6.47 \\
Document. Centre & 0.352 & 0.056 & 6.40 \\
Price & -0.056 & 0.006 & - \\
Function value -2534.24 & & &
\end{tabular}

Table 3.1: Multinomial standard logit estimates - 2816 observations

\begin{tabular}{lcccc} 
Variables & $\begin{array}{c}\text { Coefficients } \\
\text { 1st choice } \\
\text { (standard errors) }\end{array}$ & $\begin{array}{c}\text { Coefficients } \\
\text { 2nd choice } \\
\text { (standard errors) }\end{array}$ & $\begin{array}{c}\text { Coefficients } \\
\text { 3rd choice } \\
\text { (standard errors) }\end{array}$ & $\begin{array}{c}\text { Coefficients } \\
\text { 4th choice } \\
\text { (standard errors) }\end{array}$ \\
\hline Opening Time & 0.665 & 0.589 & 0.500 & 0.580 \\
Audio & $(0.133)$ & $(0.131)$ & $(0.127)$ & $(0.127)$ \\
Guides & 0.532 & 0.388 & 0.380 & 0.356 \\
& $(0.109)$ & $(0.108)$ & $(0.106)$ & $(0.106)$ \\
Café & 0.876 & 0.734 & 0.699 & 0.604 \\
& $(0.123)$ & $(0.116)$ & $(0.115)$ & $(0.117)$ \\
Exhibition & -0.155 & -0.139 & -0.372 & -0.149 \\
Events & $(0.146)$ & $(0.132)$ & $(0.132)$ & $0.127)$ \\
& 0.202 & 0.269 & 0.121 & 0.301 \\
Laboratory & $(0.129)$ & $(0.123)$ & $(0.125)$ & $(0.130)$ \\
Audiovisuals & 0.277 & 0.487 & 0.545 & 0.504 \\
Document. & $(0.143)$ & $(0.130)$ & $(0.129)$ & $(0.132)$ \\
Centre & 0.711 & 0.644 & 0.541 & 0.704 \\
Price & $(0.152)$ & $(0.139)$ & $(0.139)$ & $(0.137)$ \\
& 0.382 & 0.250 & 0.624 & 0.287 \\
Function value & $(0.122)$ & $(0.119)$ & $(0.126)$ & $(0.123)$ \\
Wald stat & 0.252 & 0.409 & 0.427 & 0.386 \\
(0.114) & -0.066 & $(0.109)$ & $(0.109)$ & $(0.111)$ \\
& $(0.012)$ & -0.052 & -0.055 & -0.052 \\
& & $(0.012)$ & $(0.012)$ & $(0.012)$ \\
& -613.0775 & -629.8240 & -632.9864 & -634.37 \\
& 7.79 & 1.46 & 5.88 & 3.75
\end{tabular}

Tables 3.2: Multinomial standard logit estimates -704 observations 


\begin{tabular}{lllllll}
\multicolumn{1}{c}{ Variables } & \multicolumn{1}{c}{ I } & $\begin{array}{c}\text { Standard } \\
\text { errors }\end{array}$ & II & $\begin{array}{c}\text { Standard } \\
\text { errors }\end{array}$ & II & $\begin{array}{c}\text { Standard } \\
\text { errors }\end{array}$ \\
\hline Opening Time & 1.782 & 0.210 & 1.654 & 0.203 & 1.634 & 0.212 \\
Audio & 1.917 & 0.366 & 3.914 & 0.507 & 5.577 & 0.855 \\
& 1.324 & 0.171 & 1.394 & 0.177 & 1.291 & 0.160 \\
Guides & 1.809 & 0.342 & 2.243 & 0.599 & 3.457 & 1.028 \\
& 2.131 & 0.243 & 2.273 & 0.241 & 2.099 & 0.229 \\
Café & 2.564 & 0.353 & 4.055 & 0.545 & 6.040 & 0.941 \\
& -0.500 & 0.171 & -0.516 & 0.181 & -0.445 & 0.172 \\
Exhibition & 1.989 & 0.316 & 3.205 & 0.557 & 4.736 & 0.725 \\
Events & 0.860 & 0.181 & 0.845 & 0.181 & 0.811 & 0.164 \\
& 0.639 & 0.654 & 0.622 & 0.869 & 2.711 & 1.499 \\
Laboratory & 1.104 & 0.194 & 1.317 & 0.218 & 1.188 & 0.205 \\
& 2.168 & 0.373 & 4.389 & 0.553 & 5.459 & 0.898 \\
Audiovisuals & 1.796 & 0.249 & 1.893 & 0.285 & 1.697 & 0.256 \\
Docum. Centre & 1.440 & 0.382 & 4.295 & 0.777 & -6.188 & 1.152 \\
& 1.133 & 0.189 & 1.294 & 0.215 & 1.168 & 0.244 \\
Price & 1.908 & 0.356 & 3.170 & 0.557 & 3.819 & 1.791 \\
& 1.464 & 0.157 & 1.112 & 0.163 & 1.067 & 0.159 \\
Function value & -0.191 & 0.32 & 2.960 & 0.441 & 3.024 & 0.595 \\
n. observations & -2212.7061 & 0.024 & -0.175 & 0.022 & -0.174 & 0.022 \\
& 2816 & 0.031 & 0.457 & 0.050 & 0.615 & 0.106 \\
& & -2210.4972 & & -2210.5876 &
\end{tabular}

Table 4.1: Mixed Logit Estimates

Notes:

I Normal distribution - Starting values: parameters in table 3.1 - Number of random draws: 4,000

II Uniform distribution - Starting values: parameters in table 3.1 - Number of random draws: 4,000

III Triangular distribution - Starting values: parameters in table 3.1 - Number of random draws: 4,000

Legend: The first row for each coefficient reports the average value, the second row reports the estimated variance (or the spread, in the case of uniform and triangular distribution) 


\begin{tabular}{lcccccc} 
Variables & I & $\begin{array}{c}\text { Standard } \\
\text { errors }\end{array}$ & II & $\begin{array}{c}\text { Standard } \\
\text { errors }\end{array}$ & III & $\begin{array}{c}\text { Standard } \\
\text { errors }\end{array}$ \\
\hline Opening time & 1.690 & 0.222 & 1.721 & 0.231 & 1.721 & 0.231 \\
& 4.108 & 0.585 & 4.005 & 0.588 & 4.005 & 0.588 \\
Audio & 1.350 & 0.181 & 1.324 & 0.173 & 1.324 & 0.173 \\
& 2.563 & 0.624 & 2.995 & 0.800 & 2.996 & 0.800 \\
Guides & 2.195 & 0.248 & 2.159 & 0.238 & 2.159 & 0.238 \\
& 4.497 & 0.611 & 3.711 & 0.675 & 3.711 & 0.675 \\
Café & -0.456 & 0.184 & -0.314 & 0.175 & -0.314 & 0.175 \\
& 3.470 & 0.483 & 3.583 & 0.555 & 3.583 & 0.555 \\
Exhibition & 0.890 & 0.179 & 0.909 & 0.193 & 0.909 & 0.193 \\
& 1.639 & 1.050 & 2.263 & 0.873 & 2.263 & 0.873 \\
Events & 1.223 & 0.232 & 1.062 & 0.207 & 1.063 & 0.207 \\
& 4.107 & 0.598 & 3.684 & 0.711 & 3.684 & 0.711 \\
Laboratory & 1.702 & 0.232 & 1.691 & 0.256 & 1.691 & 0.256 \\
Audiovisuals & -4.439 & 0.637 & 4.228 & 0.648 & 4.228 & 0.648 \\
& 1.286 & 0.256 & 1.260 & 0.220 & 1.259 & 0.220 \\
Docum. Centre & 3.071 & 0.828 & 3.213 & 0.668 & 3.214 & 0.668 \\
& 1.563 & 0.178 & 0.994 & 0.171 & 0.995 & 0.171 \\
Price & 2.467 & 0.458 & 2.571 & 0.458 & 2.572 & 0.458 \\
& -0.182 & 0.025 & -0.176 & 0.025 & -0.176 & 0.025 \\
Function value & 0.429 & 0.079 & 0.395 & 0.060 & 0.395 & 0.060 \\
n. observations & \multicolumn{2}{c}{2203.5095} & -2208.5422 & -2208.5422 \\
\end{tabular}

Table 4.2: Mixed Logit Estimates- uniform distribution

Notes:

I Starting values: 0.1 -Random draws number: 4,000

II Starting values: 0.1 -Random draws number: 40,000

III Starting values: parameters in table 3.1-Draws number: 40,000

Legend: The first row for each coefficient reports the average value, the second row reports the estimated variance (or the spread, in the case of uniform and triangular distribution)

\begin{tabular}{ccc} 
Variables & $\begin{array}{c}\text { Share of the population that } \\
\text { places a positive value on the } \\
\text { characteristic (\%) }\end{array}$ & $\begin{array}{c}\text { WTP } \\
\text { (2002 thousand lire) }\end{array}$ \\
\hline Opening Time & 71.49 & 9.78 \\
Audio & 72.10 & 7.52 \\
Guides & 79.09 & 12.27 \\
Café & 45.62 & \\
Exhibitions & 70.08 & 5.16 \\
Events & 64.43 & 6.04 \\
Laboratory & 70 & 9.61 \\
Audiovisuals & 69.59 & 7.15 \\
Document. Centre & 69.34 & 5.65 \\
Price & 27.72 &
\end{tabular}

Table 4.3: Willingness to pay for each characteristic 


\title{
CELPE's Discussion Papers
}

\author{
2007, $104 \quad$ Giuseppe CELI, Mario SPORTELLI \\ Harrod's Dynamics and the Kaldor-Thirlwall Export-led Growth \\ 2007, 103 Francesca BETTIO, Fernanda MAZZOTTA, Giovanni SOLINAS \\ Costs and prospects for home based Long Term Care in Northern \\ Italy: the Galca survey \\ 2007, 102 Lisa CROSATO, Sergio DESTEFANIS, Piero GANUGI \\ Technology and Firm Size Distribution: Evidence from Italian \\ Manufacturing \\ 2007, 101 Guglielmo Maria CAPORALE, Alexandros KONTONIKAS \\ The Euro and Inflation Uncertainty in the european Monetary Union \\ 2006, 100 Francesco Paolo VOLPE \\ Principio democratico e giustizia nell'amministrazione \\ 2006, 99 Niall O'HIGGINS \\ Still With Us After All of These Years: Trends in Youth Labour Market \\ Entry, Home-Leaving And Human Capital Accumulation in Italy 1993- \\ 2003 \\ 2005, 98 Floro Ernesto CAROLEO, Gianluigi COPPOLA \\ The Impact of the Institutions on Regional Unemployment Disparities \\ 2005, 97 Carlo ALTAVILLA, Antonio GAROFALO, Concetto Paolo VINCI \\ Is the Discouraged Worker Effect Time-Varying? \\ 2005, 96 F. BUSATO, B. CHIARINI, P. DE ANGELIS, E. MARZANO \\ Capital Subsidies and Underground Production \\ 2005, $9 Z$ Lucio Valerio SPAGNOLO, Mario CERRATO \\ No euro please, We're British! \\ 2005, 94 Roberto BASILE, Mauro COSTANTINI, Sergio DESTEFANIS \\ Unit root and cointegration tests for cross-sectionally correlated \\ panels. Estimating regional production functions \\ 2005, 93 Sergio DESTEFANIS, Raquel FONSECA \\ Matching Efficiency and Labour Market Reform in Italy. A \\ Macroeconometric Assessment \\ 2005, 92 Cesare IMBRIANI, Antonio LOPES \\ Banking System Efficiency and the Dualistic Development of the \\ Italian Economy in the Nineties
}


2005, 91 Carlo ALTAVILLA, Antonio GAROFALO, Concetto Paolo VINCI Designing the Optimal Lenght of Working Time

2005, 90 Marco MANACORDA, Barbara PETRONGOLO

Regional Mismatch and Unemployment: Theory and Evidence from Italy, 1977-1998

2004, 89 Roberta TROISI

Teoria dell'impresa e responsabilità parapenale: le implicazioni organizzativo-gestionali.

2004, 88 Roberta TROISI

Enti non profit: tipologie ed opzioni organizzative

2004, 87 Lavinia PARISI

La povertà: una rassegna sul confronto tra due approcci. Capability vs. Unidimensionalità

2004, $86 \quad$ Giuseppe CELI

Quality Differentiation, Vertical Disintegration and the Labour Market Effetcs of Intra-Industry Trade

2004, $85 \quad$ Niall O'HIGGINS

Recent Trends in Youth Labour Martkets and Employment Policy in Europe and Central Asia

2004, 84 Carlo ALTAVILLA, Floro Ernesto CAROLEO

Evaluating Asimmetries in Active Labour Policies: The Case of Italy

2004, 83 Floro Ernesto CAROLEO, Francesco PASTORE

La disoccupazione giovanile in Italia. La riforma dei sistemi

d'istruzione e di formazione professionale come alternativa alla

flessibilità numerica per accrescere l'occupabilità

2004, 82 Francesco PASTORE, Izabela MARCINKOWSKA

The Gender Wage Gap among Young People in Italy

2004, $81 \quad$ Elisabetta MARZANO

Dual Labour Market Theories And Irregular Jobs: IsThere a Dualism

Even in The Irregular Sector?

2004, $80 \quad$ Corrado ANDINI

Unemployment and Welfare Partecipation in a Structural VAR:

Rethinking the 1990s in the United States

2004, 79 Floro Ernesto CAROLEO

Fondamenti teorici della rigidità salariale nell'ambito dei "Non Market clearing Models"

2004, 78 Adalgiso AMENDOLA, Floro Ernesto CAROLEO, Gianluigi COPPOLA

Regional Disparities in Europe 
2003, 77 Fernanda MAZZOTTA

Flessibilità, povertà e istruzione: un approccio Sen - istituzionale

2003, 76 Adalgiso AMENDOLA, Annamaria NESE

Mobilità intergenerale nel livello d'istruzione nella società femminile italiana ed endogenità de titolo di studio in un modello di partecipazione alla Forza Lavoro.

2003, $74 \quad$ Antonio LOPES

Innovazione nel Sistema Creditizio del Mezzogiorno negli Anni Novanta

2003, 73 Sergio DESTEFANIS, Vania SENA

Public Capital and Total Factor Productivity New Evidence from the Italian Regions

2003, 72 Giuseppina AUTIERO, Bruna BRUNO

Social Preferences in Wage Bargaining: a Neocorporatist Approach

2003, 71 Gianluigi COPPOLA, Maria Rosaria GAROFALO, Fernanda

MAZZOTTA

Industrial Localisation and Economic Development. A Case Study

2002, 70 Francesco GIORDANO, Fernanda Mazzotta

Salario di Riserva, Probabilità di Occupazione ed Efficacia

dell'Istruzione Universitaria: un'Analisi sugli Studenti dell'Università di

Salerno

2002, 69 Giuseppe RUSSO

Istituzioni del Mercato del Lavoro e Occupazione: dai Costi di

Aggiustamento all'Appropriabilità

2002, 68 Floro Ernesto CAROLEO, Francesco PASTORE

Training Policy for Youth Unemployed in a Sample of European

Countries

2002, 67 Maria Rosaria GAROFALO, Maria Rosaria SUPINO

II Disegno Normativo del Welfare Municipale in Italia come Strumento per lo Sviluppo Economico e l'Allargamento delle Opportunità

Occupazionali. Una Lettura Neoistituzionale della L. 328/00

2002, $65 \quad$ Pietro SENESI

Cyclical dynamics under continuous time equilibrium

2001, 64 Marcello D'AMATO, Vincenzo GALASSO

E' la Riforma Dini Politicamente Sostenibile?

2001, 63 Sergio DESTEFANIS, Ornella Wanda MAIETTA

"Assessing the Productive Efficiency of Non-Profit Organisations: a

Comparative Analysis" 


\begin{tabular}{|c|c|}
\hline 2001,62 & $\begin{array}{l}\text { Floro Ernesto CAROLEO, Francesco PASTORE } \\
\text { How fine targeted is ALMP to the youth long term unemployed in } \\
\text { Italy? }\end{array}$ \\
\hline 2001,61 & $\begin{array}{l}\text { Paolo COCCORESE } \\
\text { Strategic Advertising for Entry Deterrence Purposes }\end{array}$ \\
\hline 2001,60 & $\begin{array}{l}\text { Alessandra AMENDOLA } \\
\text { Modelling Asymmetries in Unemployment Rate }\end{array}$ \\
\hline 2001,59 & $\begin{array}{l}\text { Sergio DESTEFANIS } \\
\text { Differenziali Territoriali di Produttività ed Efficienza negli Anni '90: } i \\
\text { Livelli e l'Andamento }\end{array}$ \\
\hline 2001,58 & $\begin{array}{l}\text { Giuseppina AUTIERO, Fernanda MAZZOTTA } \\
\text { Job Search Methods: the Choice between the Public and the Private } \\
\text { Sector }\end{array}$ \\
\hline 2001,57 & $\begin{array}{l}\text { Giuseppina AUTIERO, Bruna BRUNO, Fernanda MAZZOTTA } \\
\text { A Correspondence Analysis of Labour Market Institutions }\end{array}$ \\
\hline 2000,56 & $\begin{array}{l}\text { Giuseppina AUTIERO } \\
\text { Governmental Organized Learning and Coordination Problems: The } \\
\text { case of Japan in 1950s }\end{array}$ \\
\hline 2000,55 & $\begin{array}{l}\text { Giuseppina AUTIERO, Fernanda MAZZOTTA } \\
\text { The Choice of Search Methods: Some Empirical Evidence from Italy }\end{array}$ \\
\hline 2000,54 & $\begin{array}{l}\text { Giuseppe CELI } \\
\text { The Impact of International Trade on Labour Markets. The Case of } \\
\text { Outward Processing Traffic between the European Union and Central } \\
\text { Eastern European Countries. }\end{array}$ \\
\hline
\end{tabular}

2000, 53 Giuseppe RUSSO, David VEREDAS

Institutional Rigidities and Employment on the Italian Labour Market: the Dynamic of the Employment in the Large Industrial Firms.

2000, 52 Floro Ernesto CAROLEO

Le Politiche per l'Occupazione in Europa: una Tassonomia Istituzionale

2000, $51 \quad$ Andrew NEWELL, Francesco PASTORE

Regional Unemployment and Industrial Restructuring in Poland

1999, 50 Giuseppe CELI, Alasdair SMITH

Quality Differentiation and the Labour Market Effects of International Trade.

1999, 49 Giuseppe CELI

Vertical and Horizontal Intra-Industry Trade: What is the Empirical

Evidence for the UK? 
1999, 48 Cesare IMBRIANI, Filippo REGANATI

Productivity spillovers and regional differences: some evidence on the italian manufacturing sector.

1999, 47 Adalgiso AMENDOLA, Annamaria NESE

L'impatto del background familiare sul livello d'istruzione dei figli.

1998, $46 \quad$ Adalgiso AMENDOLA, Annamaria NESE

Mobilità intergenerazionale nella società femminile italiana.

1998, 45 Floro Ernesto CAROLEO, Fernanda MAZZOTTA

Youth Unemployment and youth employment policies in Italy.

1997, $44 \quad$ Annamaria NESE

Mobilità intergenerazionale in Italia

1997, 43 Adriana BARONE, Concetto Paolo VINCI

Fairness: un concetto relativo nell'analisi del mercato del lavoro

1997, 42 Adriana BARONE, Concetto Paolo VINCI

Wage differentials and factor intensity reversals

1997, 41 Rosa CAPOLUPO

L'ipotesi di convergenza nel recente dibattito sulle teorie della crescita

1997, 40 Rosa CAPOLUPO

Endogenous Vs exogenous models of growth: the convergenze debate

1997, 39 Fernanda MAZZOTTA, Annamaria NESE

Transizioni "In and Out" il mercato del lavoro in Italia: un'analisi microeconometrica

1997, $38 \quad$ Fernanda MAZZOTTA

Disoccupazione e probabilità di occupazione in Italia: un'analisi su microdati

1997, 37 Maria Rosaria GAROFALO, Bruna BRUNO

Equivalenza istituzionale" dei modelli di contrattazione sul salario: oltre il dibattito tra centralizzazione e decentramento

1997, 36 Adalgiso AMENDOLA, Floro Ernesto CAROLEO, Gianluigi COPPOLA

Differenziali territoriali nel mercato del lavoro e sviluppo in Italia

1996, 35 Adalgiso AMENDOLA

Istituzioni e mercato del lavoro. Deregolazione, occupazione e paradigma istituzionale

1996, 33 Annamaria NESE

Modelli microeconometrci per l'analisi della domanda abitativa 
1996, $32 \quad$ Annamaria NESE

Test semiparametrici per modelli parametrici

1996, $31 \quad$ Giuseppe CELI

Vertical intra-industry trade and skill intensity in Europe: a cross sector analysis

1996, $30 \quad$ Sergio DESTEFANIS

Nominal rigidities and real activity. A cross-industry analysis for Italy, 1951-93

1996, 29 Cesare IMBRIANI, Filippo REGANATI

International technology transfer into the italian manufacturing sector

1996, 28 Stefania di SERAFINO, Alberto GANDOLFI

The choice of the Government optimal procurement mechanism: the first-price sealed bid auction with one and/or two winners.

1996, 27 Raul de LUZENBERGER

Redistribution, and public debt with liquidity constraints

1996, 26 Bruno CHIARINI

Un modello VAR per la domanda di lavoro

1995, 25 Maria Rosaria CARILLO, Alberto ZAZZARO

Innovazione tecnologica e distruzione di capitale umano in un modello neo-shumpeteriano di crescita.

1995, 24 Raul de LUZENBERGER

Macroeconomia e politiche redistributive: il caso di vincoli di liquidità

1995, 23 Annamaria NESE

Tenure choice and demand for housing in Italy

1995, $22 \quad$ Filippo REGANATI

La struttura delle preferenze per prodotti orizzontalmente differenziati.

1995, 21 Sergio DESTEFANIS, Michele LA ROCCA, Cosimo VITALE Forecasting train ticket sales with linear model-based approaches and with edats

1995, 20 Stefania di SERAFINO

Bounded rationality and incomplete contracts

1995, 19 Adalgiso AMENDOLA, Floro E. CAROLEO, Maria Rosaria GAROFALO

Istituzioni, mercato del lavoro e decentramento delle decisioni.

1995, $18 \quad$ Niall O'HIGGINS

Why did the youth training scheme reduce reduce the wages of 
young people? A story of human capital formation, reservation wages and job offers.

1994, 17 Antonio CARDONE

Misure di efficienza: alcuni aspetti teorici

1994, 16 Maria Rosaria GAROFALO, Luisa ZANCHI

Neo-corporativismo, centralizzazione e dispersione inter-settoriale dei salari.

1994, $15 \quad$ Sergio DESTEFANIS

Allowing for frequency of negotiation in the aggregate wage equation.

A study for italian manufacturing, 1973/92.

1994, $14 \quad$ Marcello D'AMATO

Tariffs for a foreign industry with market power under incomplete information on demand

1994, 13 Raul DE LUZENBERGER, Cesare IMBRIANI, Giancarlo MARINI

Sustainability Issues in the process of European Integration

1994, 12 Riccardo MARSELLI, Antonio CARDONE

Interdipendenza tra regioni: un'analisi su dati di Panel

1993, 11 Adriana BARONE, Concetto Paolo VINCI

Dilemma del prigioniero e persistenza della disoccupazione involontaria

1993, 10 Maria Rosaria CARILLO

Mutamenti strutturali ed offerta di lavoro.

1993, 9 Niall O'HIGGINS

The effectiveness of YTS in Britain: an analysis of sample selection in the determination of employment and earnings

1993, $8 \quad$ Giuseppe CELI

Politiche valutarie ed integrazione commerciale: l'esperienza dello SME negli anni '80

1992, 7 Paolo COCCORESE

Attività innovativa e configurazione industriale

1992, 6 Maria Rosaria GAROFALO, Gian Luigi CORINTO

La Razionalità dell'Allocazione del Tempo di Lavoro in Agricoltura.

Con un'Applicazione Empirica ad un Sistema Locale attraverso la

PL..

1992, 5 Adalgiso AMENDOLA, Maria SCATTAGLIA

Disoccupazione e Tassi di Attività nel Mezzogiorno

1992, $4 \quad$ Floro Ernesto CAROLEO

La Disoccupazione Strutturale 
1991, 3 Giovanni URGA

Dynamic Models of Labour Demand in the Italian Industrial Sector: Theories and Evidence from Panel Data

1991, 2 Adalgiso AMENDOLA

Teoria dei Contratti Impliciti. Rigidità del Salario e Disoccupazione

1991, $1 \quad$ Guido CELLA

Sulla Integrazione Produttiva Interregionale: il Caso del Mezzogiorno 
CELPE - Centro di Economia del Lavoro e di Politica Economica Università degli Studi di Salerno

Depositato ai sensi di Legge 